\title{
Branch age in jack pine at the time of dwarf mistletoe infection
}

\author{
by Albert Sproule ${ }^{1}$
}

During a growth and yield study, 128 dwarf mistletoe (Arceuthobium americanum Nutt. ex Engelm.) infected broomed branches were collected from 47 jack pine (Pinus banksiana Lamb.) trees in north-central Alberta. The trees represented all six levels of the Hawksworth 6-class dwarf mistletoe rating system (Hawksworth 1977). As part of the growth and yield study, the dwarf mistletoe infection was aged for each branch. This provided an opportunity to assemble information on branch age at time of infection. By determining branch age at the point of infection, branch age at the time of infection was easily calculated. Branch age at time of infection in lodgepole pine was referred to by Baranyay and Smith (1972) but has not yet been reported for jack pine.

Dwarf mistletoe infections were aged by cross-sectioning through the infection at the point of maximum branch swelling and counting annual rings outwards from the first distorted ring (Baranyay and Smith 1972). As a check, a few random ages were also determined by counting the number of annual rings penetrated by the "sinkers" (roots) of the dwarf mistletoe (Baranyay and Safranyik 1970). Identical results were obtained by both methods. Ages were increased by two years to allow for the lag period between infection and initial sinker formation, i.e. the time required for germination, penetration and establishment of the parasite. The lag period has not been established for jack pine but the two-year period estimated for lodgepole pine (Pinus contorta var latifolia Dougl.)(Hawksworth and Graham 1963) should be approximately correct.

Table 1: Number of dwarf mistletoe infections by branch age at time of infection, for jack pine trees in north-central Alberta. Percentage of total infections is shown in parentheses

\begin{tabular}{ccc}
\hline $\begin{array}{c}\text { Branch age at time } \\
\text { of infection (yrs) }\end{array}$ & \multicolumn{2}{c}{$\begin{array}{c}\text { Number of dwarf } \\
\text { mistletoe infections }\end{array}$} \\
\hline 1 & 22 & $(17.2 \%)$ \\
2 & 20 & $(15.6 \%)$ \\
3 & 17 & $(13.3 \%)$ \\
4 & 10 & $(7.8 \%)$ \\
5 & 17 & $(13.3 \%)$ \\
6 & 10 & $(7.8 \%)$ \\
7 & 8 & $(6.2 \%)$ \\
8 & 3 & $(2.3 \%)$ \\
9 & 4 & $(3.1 \%)$ \\
10 & 3 & $(2.3 \%)$ \\
11 & 3 & $(2.3 \%)$ \\
12 & 1 & $(0.8 \%)$ \\
13 & 2 & $(1.6 \%)$ \\
14 & 1 & $(0.8 \%)$ \\
17 & 2 & $(1.6 \%)$ \\
19 & 2 & $(1.6 \%)$ \\
20 & 2 & $(1.6 \%)$ \\
& 1 & $(0.8 \%)$ \\
\hline
\end{tabular}

Branch age at the point of infection ranged from seven years to 50 years. Mean age was 22.71 years. Age of dwarf mistletoe infection ranged from one year to 45 years with a mean of 17.94 years. Average age of bark tissue at the time of infection was therefore 4.77 years. Distribution of branch and dwarf mistletoe ages is shown (Table 1). The distribution is heavily skewed to the younger ages with $67.2 \%$ of the infections occurring in the first five years. Although bark tissue is continually being sloughed off as branches age, it seems likely that the reduced infection rates on older branches are due to increased bark thickness. These findings are in agreement with Baranyay and Smith (1972) who stated that, in lodgepole pine, young bark up to five years is most commonly invaded and speculated that older bark is generally too thick to be penetrated by the parasite.

\section{References}

Baranyay, J. and R.B. Smith. 1972. Dwarf mistletoes in British Columbia and recommendations for their control. Report BC-X-72. Canadian Forestry Service, Pacific Forest Research Centre, Victoria, BC. 18 p. Baranyay, J. and L. Safranyik. 1970. Effect of dwarf mistletoe on growth and mortality of lodgepole pine stands in Alberta and British Columbia. Publication 1285. Canadian Forestry Service, Department of Fisheries and Forestry, Ottawa, ON. 19 p.

Hawksworth, F.G. 1977. The 6-class dwarf mistletoe rating system. USDA For. Serv. Gen. Tech. Rep. RM-48. 7 p.

Hawksworth, F.G. and D.P. Graham. 1963. Spread and intensification of dwarf mistletoe in lodgepole pine reproduction. J. For. 61: 587-591.

${ }_{1}^{1}$ Insect and Disease Branch, Alberta Land and Forest Service, 10725-120 Ave, Edmonton, Alberta Canada T5G 0S8. 